DOI No: http://dx.doi.org/10.29228/Joh.51705 Authenticity process is conducted by

Makale Türü: Araştırma makalesi

Geliş Tarihi: 09-06-2021

Kabul Tarihi: 19-08-2021

On-line Yayın: 31-08-2021
Article Type: Research article Submitted: 09-06-2021

Accepted: 19-08-2021

Published Online: 31-08-2021

Atuf Bilgisi / Reference Information

Ümit, D. (2021). "Model Partnership" between Turkey and the United States Revisited during the Syrian Conflict. Journal of History School, 53, 2336-2369.

\title{
"MODEL PARTNERSHIP" BETWEEN TURKEY AND THE UNITED STATES REVISITED DURING THE SYRIAN CONFLICT, (2009-2016)
}

\begin{abstract}
Turkey and the United States enjoyed a security-centered relationship upon the former's becoming a member of the North Atlantic Treaty Organization (NATO) in 1952. This was challenged with an envision of model partnership in 2009 to transform the relationship into a multidimensional cooperation with the mutual interests respected. Largely drawing on the materials from the White House Archives, a wide array of Presidential collections, this article aims at the careful re-reading of the construction stage of "model partnership" to demonstrate how the concept was spontaneously spelled out without being a pre-formulated and mutually endorsed policy concept and the examination of the Turkish-American relations based on the concept during the Syrian conflict up until the coup attempt of July 15, 2016 in Turkey. The article, being the first study to highlight how the concept first aired, concludes that looking into the construction stage of the notion will bear well-grounded analyses on Turkish-American relations within the concept and that the complexity of the Syrian conflict, particularly the divergent positions of the parties towards the opposition groups, called this process into question as both Turkey and the United States did not find easy agreement on aspects of their national interests and security concerns and fast moved away from the "model partnership," a vague redefinition of bilateral relations and a concept officially referred by Turkey alone.
\end{abstract}

Devrim ÜMIT'

1 Dr. Öğrt. Üyesi, Devrim ÜMİT, Karabük Üniversitesi, İktisadi ve İdari Bilimler Fakültesi, Uluslararası İlişkiler Bölümü, Uluslararası Siyaset Anabilim Dalı, devrimumit@karabuk.edu.tr, Orcid: 0000-0002-6854-3808. 


\section{Devrim ÜMITT}

Keywords: Turkey, United States, Model partnership, Syrian conflict, Turkish-American relations

\section{Türk-Amerikan İlişkilerinde "Model Ortaklık" Kavramının Suriye Çatısması Sırasında Yeniden Değerlendirilmesi, (2009-2016)}

\section{$\ddot{O} z$}

Türkiye ve Amerika Birleşik Devletleri, Türkiye'nin 1952 yılında Kuzey Atlantik Antlaşma Örgütü (NATO) üyesi olmasıyla birlikte güvenlik merkezli bir ilişki kurup geliştirdiler. Bu durum 2009 yılında, ortak çıkarlara saygı duyulduğu çok boyutlu bir ilişkiye evrilmesini amaçlayan, model ortaklık tasavvuru ile değişime uğradı. Çok çeşitli Başkanlık koleksiyonlarından oluşan Beyaz Saray Arşivlerine dayanarak kaleme alınan bu makale, "model ortaklık" kavramının oluşum sürecinin, sözkonusu kavramın önceden formüle edilen ve karşılıklı olarak kullanılan bir siyasi kavram olmaksızın, spontane olarak ortaya çıktığını göstermek suretiyle, yeniden dikkatli bir şekilde okunmasını ve bu kavrama dayanan Türk-Amerikan ilişkilerinin, Suriye çatışmasında Türkiye'deki 15 Temmuz 2016 tarihli başarısız darbe girişimine kadar olan kesiminin incelenmesini amaçlamaktadır. Söz konusu kavramın ilk kez nasıl ortaya çıktığını gözler önüne seren ilk çalışma olma özelliğini taşıyan bu makele, sonuçta "model ortaklık" kavramının oluşum aşamasına bakmak suretiyle hem Türk-Amerikan ilişkilerinin bu kavrama dayalı olarak yapılan analizlerin daha sağlam temeller üzerinde inşa edilmesini sağlayacaktır hem de Suriye krizinin karmaşık yapısının, özellikle tarafların Suriye'deki muhalif gruplara yönelik farklı şekillerde konum almalarının, "model ortaklık" sürecinin sorgulanmasına yol açtığını göstermektedir. Zira bu makale ortaya koymaktadır ki Türkiye ve Amerika Birleşik Devletleri, Suriye çatışması sırasında, ulusal çıkar ve güvenlik sorunları konusunda ortaklaşamamış ve zaten ikili ilişkilerin muğlak bir ifadesi ve sadece Türkiye tarafından atıfta bulunulan bir kavram olmaktan öteye gidemeyen "model ortaklık" kavramından hızla uzaklaşmışlardır.

Anahtar Kelimeler: Türkiye, Amerika Birleşik Devletleri, Model ortaklık, Suriye çatışması, Türk-Amerikan ilişkileri

\section{INTRODUCTION}

Starting with Turkey's becoming a North Atlantic Treaty Organization (NATO) member in 1952 under which the country became the crucial part of the transatlantic defense system with its second-largest armed forces following the United States, Turkey and the United States enjoyed a relationship that prioritized security concerns. Except for a brief period in the post-Cold War era when uncertainties about the nature of post-Soviet politics raised questions about 
“Model Partnership" Between Turkey And The United States Revisited During The...

Turkey's geo-strategic and geo-politic importance, the country has generally maintained its significance for NATO and the American policy in the Middle East. Over the last twelve years, particularly the course of the Syrian conflict, taken as a key variable in the present study, has caused the bilateral relationship to fluctuate, and the countries have gradually found themselves drifting apart.

Turkey's role in American global policy was traditionally predicated on the continuation of East-West conflict, and Turkey's role in Middle Eastern regional affairs was assumed to be of secondary importance. Though the end of the Cold War brought with it many changes in world affairs, the particular case of Turkey stands out theoretically because of its unique position as a member of NATO, but not of the European Union. The American Department of State continues to treat Turkey under the rubric of "Europe," rather than "Near and Middle East." Yet today, the primary questions which the United States posing regarding Turkey's international position relate to Syria, Iraq, and Iran. Thus it may be that future articulations of American foreign policy will relocate Turkey at a conceptual level and thus change the traditional model of bilateral relations.

Were Turkey to become, in American eyes, primarily a locus of regional contestation with steadily diminishing relevance to world politics at a global level, the resulting changes in American policy toward Turkey, and vice versa, could undergo substantial change. Turkey's ability to remain aloof from regional crises, such as the Lebanese civil war (1975-1990), the Iranian Revolution (1979), a series of conflicts between Israel and supporters of the Palestinian cause, and the post-9/11 American interventions in Afghanistan and Iraq, has buttressed rather than challenged the Turkish-American bilateral relationship. Only with the Syrian conflict, in all of its dimensions, including involvement by foreign powers like Iran and Russia, a strong political and military mobilization of Kurdish forces, and the challenge to Syria's national and territorial integrity generated by the self-proclaimed Islamic State (IS), ${ }^{2}$ has regional involvement become so central to Turkish foreign policy that it has begun to supersede the longstanding pattern established during the Cold War which overlapped with the transitional period that both Turkey and the United States were going through in the first decade of 2000 s.

2 The present study follows this chronology in the use of the terms ISIL, ISIS, and IS. This runs parallel to the chronology of the study.

[2338] 
For Turkey, at domestic level, the Justice and Development Party (AKP, Adalet ve Kalkınma Partisi in Turkish), ${ }^{3}$ coming to power in 2002, aimed at democratization and transformation of Turkey in political, economic, and societal terms. At regional level, based on foreign policy parameters of "strategic depth" by the Minister of Foreign Affairs, the AKP targeted to develop multidimensional relations with the entire neighboring countries, formulated as "zero problems with neighbors," particularly with those in the Middle East while undertaking a "central" role in the region. ${ }^{5}$ At global level, the AKP government led by then Prime Minister Recep Tayyip Erdoğan ${ }^{6}$ envisioned to become a worldwide political and economic power, targeting to be one of the 10 largest economies in the world by 2023 . Turkey, indeed, in 2014 became the $18^{\text {th }}$ largest nominal GDP and the $17^{\text {th }}$ GDP by purchasing power parity ${ }^{7}$ and made agreements with key countries, such as Jordan, Syria, and Lebanon in the Middle East and Libya in North Africa to mutually lift the visas while starting to reach the Far East, Latin America, and Africa, left off tangent until then by the traditional foreign policy establishment.

Regarding the United States, President Barack Obama took office under a financial crisis with global implications and with urge to keep his pre-election campaign words to repair the country's badly damaged relations with the Muslim world and the Middle East following the American military intervention of Iraq in 2003, as a result of the "War on Terror" as articulated by President George W. Bush in the immediate aftermath of the 9/11 terrorist attacks in 2001. Therefore,

3 Turkish political party names will be provided in their Turkish acronyms when mentioned as a second time.

${ }^{4}$ Davutoğlu, Stratejik Derinlik; Davutoğlu, "Principles of Turkish Foreign Policy and Regional Political Structuring." Next to Erdoğan, Turkey's foreign policies under AKP in general and during the Arab uprisings and the Syrian conflict at particular were largely crafted by Davutoğlu, an academic and Minister of Foreign Affairs (May 2009-August 2014) and Prime Minister (August 2014-May 2016). These policies reflected his vision of Turkey as a regional and global player.

${ }^{5}$ Rejecting the Cold War lexicon such as "southern flank" or "frontline state" as well as the Post Cold War conceptualizations such as "pivot" or "bridge," Davutoğlu redefines the role of Turkey as a "central country" both at regional and global level, while centralizing the historical and geographical status of the country within its foreign policy through a neo-Ottoman Islamist outlook. Davutoğlu, "Türkiye Merkez Ülke Olmalı."

${ }^{6}$ Turkish person and place names are provided in their original spelling. Words that are common in English are given in their common usage. For example, instead of "İstanbul," I opt for "Istanbul."

${ }^{7}$ IMF World Economic Outlook Database, Report for Selected Countries and Subjects. 
“Model Partnership” Between Turkey And The United States Revisited During The...

Obama, in his first term in the White House (2009-2012), made a special effort to start a new dialogue with the Islamic world while abandoning the lexicon and evangelical rhetoric of the previous presidency and paid his first overseas visit to Turkey, a Muslim majority, yet secular and democratic country. The Obama administration further prepared the country for the withdrawal of American combat troops from Iraq as planned for August 2010. ${ }^{8}$

Arab uprisings, transforming the Middle East and North Africa (MENA) region from Tunisia to Bahrain while dethroning the long-seated authoritarian regimes, brought a new dynamic to the Turkish-American relations. The Syrian conflict, the most complicated case of the uprisings, presented both countries new opportunities and challenges. The rising of Turkey as a regional and global power with its geostrategic importance and the fact that the United States needed Turkey as a partner in the Middle East to revive its relations with the Muslim world initiated a new era between the parties. The fresh rapprochement was particularly important for succeeding the troublesome early 2000s when the Turkish Grand National Assembly initially refused to allow the American troops to invade Iraq through Turkey. However, the Syrian conflict, chiefly the civil war, demonstrates that the rapprochement is in its infancy and may stumble down given the multilayered aspects of the conflict and how the parties have addressed those aspects within their national interests and security concerns.

Therefore, the article, whilst investigating the Turkish-American relations during the Syrian conflict up until the failed coup of July 15, 2016, aims at demonstrating how the concept of "model partnership" was accidentally constructed and unilaterally referred by Turkey and argues how Turkey and the United States positioned themselves in the Syrian civil war and to the opposition groups, primarily the People's Defense Units (YPG), ${ }^{9}$ armed wing of the Democratic Union Party (PYD), under the rubric of their national interests and hard security concerns were decisive in their fast moving away from the "model partnership," already an imprecise redefinition of the bilateral relations under Obama's presidency.

8 https://obamawhitehouse.archives.gov/the-press-office/remarks-president-obamaturkish-parliament April 6, 2009.

${ }^{9}$ YPG is the Kurdish acronym for the People's Defense Units organized in Syria in 2004 and is the military branch of PYD, Kurdish acronym for the Democratic Union Party established in 2003 as one of the Kurdish opposition parties under the Parliament of Syria.

[2340] 


\section{Devrim ÜMITT}

\section{METHOD}

Methodologically, the existing model until recently has been Cold War bilateralism in which the geopolitics of the Cold War takes precedence over any concerns about Turkey's internal or economic vicissitudes. The global structure of the East-West was so strong that it regularly took priority, from a U.S. point of view, over regional concerns. The old "twin pillar" policy in the Gulf that relied on the Shah and the Saudi monarchy to keep oil flowing and tamp down leftist movements provides an example. Therefore, analysts focused on Cold War bilateralism paid minimal concern to the details of regional affairs. That applied to Turkey from accession to NATO to the fall of Communism. The model which has recently been emerging is "regional balancing," something the United States has been interested in for decades with regard to Egypt, Iran, Israel, and Saudi Arabia. Those analysts, by contrast, interested in regional balancing have devoted an enormous amount of time and energy to small, yet significant details of internal state politics, such as the fifteen-year Lebanese civil war, and bilateral threats and counter-threats between, say, Israel and Syria, or Syria and Iraq, or Jordan and any country else.

Of the three traditional American foreign policy concerns about the Middle East, the biggest, namely, denial of Soviet penetration and influence was centermost for Cold War bilateralism. But the other two, preservation of Israeli political and military superiority ${ }^{10}$ and uninterrupted flow of oil, were deeply involved with regional balancing. However, in the course of the Syrian civil war, scoring the IS as the top threat to its national interest and cooperating with the YPG on the ground, the United States gave the early signs of recognizing the Kurds, only after Israel and the secure flow of oil, as one of the pillars of American policy in the Middle East and one of the key priorities for its national security. If a shift is taking place from one model to the other, it stands to reason that the emerging methodology will involve a deep look into how the "model partnership" was constructed through the examination of primary official documentation and the attention of details of conflict and tension, with a legitimate emphasis on newspaper accounts because they play such a huge role in shaping local public opinion and thus the sense people have of how the regional balance is evolving. The present study, with its particular look into the construction stage of "model partnership" largely drawing on the materials from the White House Archives, is appropriate to its argument of a model shift from

${ }^{10}$ https://obamawhitehouse.archives.gov/the-press-office/2015/12/09/remarks-presidentobama-and-president-rivlin-israel-bilateral-meeting December 9, 2015. 
“Model Partnership" Between Turkey And The United States Revisited During The...

Cold War bilateralism to regional balancing. From the standpoint of American thinking about Turkey today, small and local events along the Syrian and Iraq borders, relations with Iran, and declarations of hostility or cooperation respecting Israel, Saudi Arabia, the Kurds, and the like are precisely the way of exploring my topic while not restricting itself to a debate of theoretical analyses or targeting at quantative approach.

There is a wide body of literature addressing the "model partnership" between Turkey and the United States and the bulk of this literature took place at its early stage given the wide excitement and anticipation that the new concept generated in academic and policy-making circles, while some of the analyses and studies unfolding at a later stage provided linear evaluations without crediting the Syrian conflict, which led Turkey and the United States to abandon a working relationship, let alone a traditional pattern of a partnership. The reason for the relatively low reference to model partnership in later literature might primarily be for the fact that the concept, once the newly shaping pattern of the bilateral relations, an expectation only on the part of Turkey as demonstrated by the present study, has lost most of its relevance in the turbulence of the Syrian civil war.

Some of the early analyses and studies delve into a theoretical debate with a skeptical outlook, such as conceptually evaluating the paradigm as an "empty signifier" given the "all-encompassing" and "not well-defined" nature of the partnership as the bilateral relations moved from a "hierarchical" stage to a "complementary" one in the early 2000s which made the "redefinition" of the relationship imperative, particularly from a perspective of the United States. ${ }^{11}$ Crediting Turkey's desire to bandwagon regionally and globally as well as to apply omnibalancing policies under the AKP rule, Ahmet K. Han, writing in mid2010, while holding the idea that the relation may still have some pragmatic and instrumental value for both sides, concludes that no partnership could be qualified unless it is "real" and "contextualized" through "shared interests" as well as "common values and principles."12 On the other hand, some of the early literature welcomed, yet cautiously the new concept upon its first official announcement as the harbinger of "a new chapter" in bilateral relations, ${ }^{13}$ and some other embraced the novel conceptualization mainly given the synchronized

\footnotetext{
${ }^{11}$ Y1lmaz, "US-Turkey Relations: Model Partnership as an 'Empty Signifier."

12 Han, "From 'Strategic Partnership' to "Model Partnership": AKP, Turkish-US Relations and the Prospects under Obama."

${ }^{13}$ Alirıza, "President Obama's Trip to Turkey: Building a 'Model Partnership."
} 


\section{Devrim ÜMITT}

policies of both countries, yet not free of opinions of divergence, during the Arab uprisings. ${ }^{14}$

In course of time, the analyses and studies seem to better position themselves for an overall and conceptual inquiry of the model partnership. However, most of the subsequent literature tend to debate the feasibility or the possibility of model partnership or a partnership alone through an en masse treatment of the developments in the Middle East from the Arab uprisings to the Syrian conflict and the developments in Turkey without examining how the notion of "model partnership" was accidentally constructed and demonstrating that the magnetic concept was officially referred by Turkey alone. Largely drawing on the materials from the White House Archives, as a wide spectrum of Presidential collections of speeches and remarks, press briefings, and statements and releases were scrutinized, the present article will be the first study to indicate that unlike its treatment as a U.S. or a Turkish foreign policy formulation by analysts, the notion first aired during the question and answer session of a joint press conference by Turkish President Gül and President Obama when the latter paid his first official visit in 2009 and that since then, the concept, as if it were an officially pre-formulated U.S. coinage, was officially referred by Turkey unilaterally until completely losing its relevance during the heyday of the Syrian civil war. Therefore, revealing how the "model partnership" was founded will lead to well-grounded analyses of Turkish-American relations based on the concept for the time- period in question. The article concludes that the divergent positions of Turkey and the United States during the Syrian civil war, particularly towards the opposition groups, led the parties to fast move away from a workable or a traditional relationship, let alone a "model partnership," already a vague redefinition of the bilateral relations and that the harmonization of policies of both parties towards the opposition groups through a shared set of values may harbor a challenge to the traditional pattern of the relationship.

\section{FINDINGS AND INTERPRETATION}

In the beginning of his first term in office, President Obama tried to reach out the Muslim world. Significant position of Turkey and its aptitude to have dialogue with its neighbors in the Middle East made Ankara a perfect choice for Washington to start fresh with the region. Therefore, Obama in April 2009 chose

${ }^{14}$ Üstün, "US-TR Relations: Arab Spring and the Search for Model Partnership.” Kardaş, "Turkish-American Relations in the 2000s: Revisiting the Basic Parameters of Partnership?" 
“Model Partnership” Between Turkey And The United States Revisited During The...

Turkey to be the last stop of his first overseas visit at a time when Obama and then Prime Minister Recep Tayyip Erdoğan were at the climax of their popularity among their own nation and in the world. The visit included a gathering with Turkish President Abdullah Gül ${ }^{15}$ following which in a joint press conference, Obama first time mentioned the "model partnership" 16 as well as an historic appearance of himself before the Turkish Assembly which made Obama only second to former President Bill Clinton to make remarks in the Assembly ${ }^{17}$ and a subsequent meeting with Erdoğan ${ }^{18}$ in that order.

It is of high significance to mention that during the joint press conference both Gül and Obama showed agreement with extending the strategic relationship based on military and political cooperation as well as on fighting against extremism to the development of economic and technology cooperation. However, it was only in the question and answer session, in response to a question about where his presidency would be different from Bush presidency concerning the Turkish-American relations that Obama provided a straightforward answer, that is, it would be where there was "the most promise of building stronger U.S.Turkish relations [with the] recognition that" the United States and Turkey, a "predominantly Christian" and a "predominantly Muslim nation," a "Western nation" and a nation "straddle[ing] two continents" could build a "model partnership" with "similar set of principles," such as freedom, rule of law, and religious freedom. This would further enable the creation of a "modern international community," which was secure, respectful, and prosperous as there were no "inevitable tensions between cultures" by which Obama exposed his disbelief in the much-debated clash of civilizations as earlier in his speech he underlined the need for "a set of strategies that [could] bridge the divide between the Muslim world and the West" where Turkey could play its part for lying "at the crossroads between East and West." That's why, he tried to "make a statement by ending his long week trip in Turkey,"19 which he would further

${ }^{15}$ MacLean, Abdullah Gül and the Making of New Turkey.

16 https://obamawhitehouse.archives.gov/the-press-office/joint-press-availability-withpresident-obama-and-president-gul-turkey

http://www.presidency.ucsb.edu/ws/?pid=85974, April 6, 2009.

17 https://obamawhitehouse.archives.gov/video/Addressing-the-Turkish-Parliament April 6, 2009.

18 https://obamawhitehouse.archives.gov/the-press-office/remarks-president-and-pmturkey-after-meeting April 6, 2009.

${ }^{19}$ In the context of bridging the East and West, President Obama might try to make another statement when he chose Athens, Greece to be his final trip overseas as the U.S. 
emphasize in his subsequent Turkish Assembly speech. In American president's eyes, a "model" partnership between the United States and Turkey would testify to the feasibility of a partnership between two different cultures which might further serve as a microcosm to the cooperation between the Muslim world and the West and to the interfaith relationship. This well suited to the global agenda of Turkey under the AKP rule.

Therefore, "model partnership," was not a Presidential doctrine or statement; it was neither a pre-designed policy term nor a pre-determined agenda on the part of Obama presidency, rather a word spelled out spontaneously upon a specific question during a press conference. That is why, Obama, in any of his subsequent speeches and remarks during his visit in Turkey, including his remarks in the Turkish Assembly, with Premier Erdoğan or in his gathering with young Turkish students in Istanbul, did not mention of "model partnership." Even in his next talk in few hours in the Assembly, which reads within the same parameters of his remarks with Gül, the U.S. President did not pronounce the concept.

It was the Turkish side which drew off the word and gave a "meaning" to it, almost as if it were a formally conceptualized American policy where both countries agreed on. In fact, Erdoğan in his meeting with Obama in December the same year did not shy away from confessing that they gave "greater meaning to the term "model partnership." ${ }^{20}$ This would become a pattern on the part of Turkish and American sides in the future, that is, in the course of seven years up until the Turkish coup attempt of July 2016, when the high officials of both countries at capacities of variety gathered in any official setting, whether it was an official visit or a bilateral meeting on the margins of a conference or summit, or a phone call, it was only the Turkish party who did make a reference to "model partnership," sometimes to the extent of an over-characterizing. Though the U.S. remained committed to pursue a multidimensional cooperation with Turkey, the reading of the U.S. primary official documents almost give the impression that the American side avoided using the concept, whilst most of the time preferring

President, https://obamawhitehouse.archives.gov/the-press-office/2016/11/16/remarkspresident-obama-stavros-niarchos-foundation-cultural-center November 16, 2016.

${ }^{20} \mathrm{https}$ ///obamawhitehouse.archives.gov/the-press-office/remarks-president-obama-andprime-minister-erdogan-turkey-after-meeting December 7, 2009. 
“Model Partnership" Between Turkey And The United States Revisited During The...

to define its counterpart as an "ally," "friend," "strategic partner," "NATO ally" or "southern flank," mostly reminiscent of the Cold War lexicon.

Model partnership was not an U.S. official announcement or formulation. Rather, it did emerge within a civilizational connotation as explained above and has remained as a unilaterally referred policy item by the Turkish party. Although both countries were determined to move forward on the different dimensions of the bilateral relationship, this should not overshadow the fact how the notion was first coined. Despite the buzz and optimism as well as a whole genre of conceptual, theoretical, and practical debates which the concept engendered in academic and policy-making circles, even one single study within the abundant literature on the Turkish-American model partnership has so far neither scrutinized nor has taken notice of how this concept was constructed. Inasmuch as the lack of study or the intentional or unintentional negligence of the formulation stage may well lead to the misreading and overstated analyses of the topic, through a careful re-reading of the construction period of the "model partnership" by the examination of primary official documentation, namely, the White House Archives, ${ }^{21}$ the present study will fill the gap in the literature in that regard and will lead to well-grounded analyses on the concept.

During Obama's visit, both parties underlined the key points of foreign policy agendas including Iran, within nuclear non-proliferation, the unity of Iraq, Israel and Palestine, treatment of the Kurds in the Middle East, mainly within the democratization efforts in Turkey, and the common fight against extremism as symbolized with the U.S. fight against al-Qaeda. Recognizing the regional and international prominence of Turkey especially during his remarks in the Turkish Assembly as a country "at the crossroads of continents," where "East and West" not divides, but meets and as a "critical ally," Obama strongly underlined "America's commitment to one strong and enduring friendship" of Turkey. ${ }^{22}$

However, given his ultimate goal to mend fences badly damaged during the Bush presidency, Obama's concentration was to extend a message to the Muslim world from the Turkey stage under the roof of the Turkish Parliament, through an unequivocal statement that "the U.S., is not, and will never be, at war with Islam" and their "partnership with the Muslim world" will be a "critical" one not only for "rolling back the violent ideologies," but also to "strengthen

${ }^{21} \mathrm{https}$ //obamawhitehouse.archives.gov/briefing-room/speeches-and-remarks

22 https://obamawhitehouse.archives.gov/video/Addressing-the-Turkish-Parliament April 6, 2009. 
opportunity for all its people." Calling on his own Muslim roots and aiming to "bridge the misunderstandings" and to "seek common ground" with the Muslim world, Obama spoke out that America's relationship with the latter would not just be based on "opposition to terrorism," but would search for a "broader engagement based on mutual interest and mutual respect": "our focus will be on what we can do, in partnership with people across the Muslim world to advance our common hopes and common dreams." 23

Therefore, in his subsequent meeting with Erdoğan, the Turkish Premier found great joy in calling Obama with his full name including "Hussein," yet still defining the U.S. as a "strategic partner," with whom the status of bilateral relations would be reviewed in return which Obama consumed a similar content and terminology in that their relationship with Turkey as a "critical strategic ally" was not only to be defined in "combatting terrorism," but was to extend to develop economic, cultural, and political links. ${ }^{24}$ It is interesting to note that during his gathering with Erdoğan, Obama preferred to refer to his remarks in the Turkish Assembly, not to those in his joint press conference with Gül when he first time spoke the "model partnership." In the following roundtable discussion with a group of young students in Istanbul, Obama made quite an enthusiastic speech full of promises indicating where his country stood at the moment while exposing his full name and calling on his personal Islamic heritage as well as heralding the "new chapter" he was about to open at world stage and the multidimensional relationship, including the venue of education, he was seeking to build with Turkey while reckoning the Robert College of Istanbul. ${ }^{25}$

Overall, during his first and only exclusive visit to Turkey, Obama's remarks and speeches were more of a civilizational connotation ${ }^{26}$ with pragmatic

${ }^{23}$ Ibid.

24 https://obamawhitehouse.archives.gov/the-press-office/remarks-president-and-pmturkey-after-meeting April 6, 2009.

25 https://obamawhitehouse.archives.gov/the-press-office/remarks-president-barackobama-student-roundtable-istanbul April 7, 2009.

${ }^{26}$ The civilizational aspect of Obama's outlook towards the new era between the Muslim world and the United States under his presidency reached the climax in his mostanticipated "big talk" to the Muslim world as held in Cairo University of Egypt, just two months after his Turkey visit, where the U.S. President welcomed the packed hall with an Arabic phrase of Islamic connotation to announce the "new beginning" between the United States and the Muslim world based on "mutual interest and mutual respect" where America and Islam would not be "exclusive" of each other and in competition, but would be bound by "common principles" of humanity such as justice, progress, and dignity, 
“Model Partnership” Between Turkey And The United States Revisited During The...

and eclectic tones and with less reference to the strategic aspects of the TurkishAmerican relationship while both Turkey and the United States demonstrated their eagerness for the new modes of cooperation. Despite the pattern how "model partnership" surfaced and its unofficial status, the accidental concept attracted Turkish policy makers and intellectuals who were impatient to integrate the geostrategic importance and socio-cultural dynamics of Turkey into regional and world politics, and the prospect for a new model of partnership credited their ambitious plan for the country's multidimensional, multiregional, and multisectoral foreign policy framework. The prospect of a flexible, inclusive, and comprehensive concept, as there would be no conceptual consensus of what might constitute the concept, left space for Turkey to better formulate and publicly embrace the notion in the months to become. "Model partnership," was about to become a magnetic motto for Turkey in its attempt to re-define the new epoch in bilateral relations, and the practice took place with Erdoğan's visit in turn to Washington in early December 2009 where the Turkish Premier first time pronounced the phrase to improve the "many sides" of the bilateral relationship including the areas of "science, art, technology," as well as those of economy, politics, and military. ${ }^{27}$

Conversely, the chain of developments in Turkish foreign policy concerning the Middle East, such as the Tehran Joint Declaration, Mavi Marmara incident, and Turkey's no vote in the United Nations Security Council against the sanctions to Iran posed serious challenges to model partnership and drew in Washington a widespread conception of "axis of shift" 28 in Turkish foreign policy

https://obamawhitehouse.archives.gov/issues/foreign-policy/presidents-speech-cairo-anew-beginning June 4, 2009; The echo of Obama's Cairo speech was so overwhelming that the Turkish President Gül called him to congratulate and seized the moment to "continue to partner together to address common challenges to our security and prosperity around the world," https://obamawhitehouse.archives.gov/the-press-office/readoutpresidents-call-with-turkish-president-gul July 5, 2009.

${ }^{27} \mathrm{https}$ ///obamawhitehouse.archives.gov/the-press-office/remarks-president-obama-andprime-minister-erdogan-turkey-after-meeting December 7, 2009.

${ }^{28}$ Şahin, "Islam, Ottoman Legacy, and Politics in Turkey: An Axis of Shift"; Çandar, “Turkey's 'Soft Power' Strategy: A New Vision for a Multi-Polar World"; Öniş, "Multiple Faces of the 'New Turkish Foreign Policy: Underlying Dynamics and Critique"; Oğuzlu, "Middle Easternization of Turkish Foreign Policy: Does Turkey Disassociate from the West"; Oktav, "Regionalism or Shift of Axis? Turkish-SyrianIranian Relations"; Başer, "Shift of Axis in Turkish Foreign Policy: Turkish National Role Conceptions before and during AKP Rule"; Özhan, "Turkey, Israel, and the US in the Wake of the Gaza Flotilla Crisis." 


\section{Devrim ÜMITT}

in that Turkey was moving eastward from the West and departing from the traditional emphasis on its Western allies, including the North Atlantic Treaty Organization (NATO) and the European Union (EU). This assertion was rather a misunderstanding of foreign policy circles outside Turkey. In fact, Turkey was applying new schemas and policies at regional and global level in respond to the fast changing milieu of the post-Cold War period at a time when the country was attempting to play a leading role in its region and the world which could only be achieved through a multi-centered and inclusive foreign policy agenda of high competency. Nonetheless, Turkey's no vote further strained the relations since Washington interpreted Ankara's newly shaping foreign policy to be against to its own core interests. This reminded the March 2003 crisis when the Turkish Assembly initially did not allow the use of NATO air bases before the American military operation in Iraq. At the peak of such a difficult period in mid-2010, Erdoğan and Obama met briefly during a G-20 summit in Canada in late June 2010 and subsequently, channels of dialogue were reopened to maintain the venues of cooperation (World Bulletin, June 27, 2010).

Arab uprisings shaking the entire MENA region with transformative changes while toppling off one dictator after another from Tunisia to Libya provided Turkey and the United States with a venue of cooperation as both countries applied similar policies in respond to the uprisings and embraced the public movements against the authoritarian regimes and their legitimate demands despite initial standpoints of difference, such as in the cases of Egypt and Libya. Marking the closure of Cold War order in the region and predicting a new era with structural changes, the Arab unrests manifested that a "model" partnership was achievable when interests were mutual, till the Syrian conflict took stage.

The Syrian conflict has been the Achill's heel of the Arab upheavals. Similar to the concurrent uprisings in the MENA region, it started as antigovernment and pro-democracy demonstrations in March 2011, but turned into a full-scale civil war shortly. Given the historical background and the multireligious, multiethnic, multisectarian, and the polyglot nature of the country, the conflict in Syria transformed to a multilayered conflict with regional and worldwide repercussions and became the fiercest shake of the regional earthquake with a devastating civil war of nearly half million death toll and 11 million displaced people, the bulk of whom found refuge in neighboring countries, thereby causing the worst humanitarian crisis in recent years and with the emergence of a terrorist organization, the IS, formerly known as ISIL or ISIS, 
“Model Partnership" Between Turkey And The United States Revisited During The...

which has a regional and global claim since June 2014 while occupying Iraq and Syria and applying brutal tactics, which instigated universal outrage.

At the outset, the United States did not ignore the opposition groups fighting against President Bashar al-Assad while keeping the channels of dialogue open with the regime. Turkey initially sought ways to persuade Assad to make reforms, but shortly took an irrevocable anti-Assad stance under Erdoğan's premiership and presidency. Although its early stage was drawn within "strategic depth," Turkey's Syria policy has largely been formulated by Erdoğan $^{29}$ and its reaction to the Syrian refugee crisis was the reflection of the country's becoming more responsive to regional and global conflicts. Opening its doors to the massive influx of Syrian people of diverse backgrounds and providing them with temporary protection based on open-door policy and the principle of non-refoulement, Turkey became the largest host country with three million registered Syrian refugees to be followed by Lebanon, Jordan, Iraq, and Egypt in that order at the time. ${ }^{30}$

Obama's policy towards Syria and Assad mirrored his pre-election promises to normalize the relations with the Muslim world and the Middle East, and Syria was the key partner to restart the Israeli-Arab peace negotiations. However, Arab uprisings unexpectedly disrupted Obama's plans about Syria. Although in the beginning of the Syrian conflict, Obama sought for ways to work with Assad to resolve the difficulties between the regime and the opposition groups, the brutal crackdown of the demonstrators despite the warnings by the international community including the United States left no choice to Obama, but to side with opposition groups while not closing the doors to Assad entirely.

The Syrian conflict was the chief test for Turkey's newly shaping foreign policies as maneuvered by Erdoğan as well as for Obama and the novel patterns of partnership. Both administrations tried to persuade Assad to make reforms

${ }^{29}$ Erdoğan was elected the $12^{\text {th }}$ President of Turkey in early August 2014 with a simple majority of the votes, nearly 52 percent, in the first round of a two-round election where three candidates ran for presidency. He became the first president elected by people's votes in Turkey's modern history until which presidents were elected by the Turkish Assembly according to the Constitution envisaging a parliamentary system. The outcome gave boost to Erdoğan's ambitions to change the Constitution for a presidential system. The turnout in the presidential elections was low, 75 percent, in comparison to the following general elections in June 2015 where it was 85 percent.

${ }^{30}$ https://data.unhcr.org/syrianrefugees/country.php?id=224 updated June 30, 2016, the site provided almost minute-updated status of the Syrian refugees. 
consistent with public demands; when these efforts failed, they took on a position of Assad's removal. Turkey employed all possible means including the "train and arm" program mainly for detectors from the Syrian Arab Army. The program led to the establishment of the Free Syrian Army (FSA), provided safe haven by Turkey which displeased Assad. This became one of the reasons for the downing of a Turkish fighter jet by the Syrian forces and the subsequent border clashes in 2012. Regarding the United States, Obama, in the summer of 2011, issued a statement asking Assad to "step aside" which was endorsed by British, German, and French Premiers. It was the first time Obama made an explicit public announcement asking Assad to resign (The Washington Post, August 18, 2011) and was reiterated during his visit under G-20 summit to Turkey in late 2015. ${ }^{31}$ However, his emphasis on Assad's resign never reached Erdoğan's rhetoric as Obama prioritized the fight against the IS.

Following his call on Assad to resign and his order for all Syrian government assets in the U.S. to be frozen, Obama and Erdoğan, in late September 2011, gathered for a bilateral meeting on the margins of the annual session of the U.N. General Assembly in New York. Taking place also in the immediate aftermath of the blasts and attacks on civilians in Turkey, both leaders demonstrated commitment to fight against terrorism. Obama made no mention of model partnership while defining Turkey as a "NATO ally, a great friend, and partner" as opposed to Erdoğan, choosing "model partnership" to start with his remarks. ${ }^{32}$ When the two leaders gathered again six months later, this time, on the sidelines of a Nuclear Security Summit held in Seoul, Korea, in March 2012, approaches of both countries to the concept were same, while they agreed on "a transition to a representative and legitimate government in Syria." Reserving a high appraisal for Turkey's stance towards the Syrian refugees, at the time only 17,000 of them were hosted by the country, Obama continued to call Turkey as an "outstanding partner" and an "outstanding friend," while Erdoğan even made a stronger reference to the concept through his closing remarks that they

\footnotetext{
31 https://obamawhitehouse.archives.gov/the-press-office/2015/04/21/statement-nscspokesperson-bernadette-meehan-national-security-advisor-s April 21, 2015; https://obamawhitehouse.archives.gov/the-press-office/2015/03/26/readout-president-scall-president-recep-tayyip-erdogan-turkey March 26, 2015.

32 https://obamawhitehouse.archives.gov/the-press-office/2011/09/20/remarks-presidentobama-and-prime-minister-erdogan-turkey-bilateral-meet September 20, 2011.
} 
“Model Partnership" Between Turkey And The United States Revisited During The...

"upgraded the status of [their] relations from a strategic partnership to a model partnership" since Obama took office. ${ }^{33}$

The civil war in Syria reflects the country's deeply-rooted complexity transcending its multiconfessional, multisectarian, multiethnic, and polyglot formation without disproving the transhistorical virtues of diversity, tolerance, and co-existence. The war is not simply between the Alawite-dominated government forces and the opposition groups of various ethnic, religious, and sectarian backgrounds. It is a war within a war that builds on the struggle of these ethnic and religious groups to define their separate and autonomous cultural and physical entities and on the competition among the opposition groups. In a milieu of transition and uprisings standing as a characteristic of the autocracy's failure and the reappearance of religious fundamentalism, the IS and the al-Nusra, known as the al-Qaeda in Syria, have fought against the regime forces which have sporadically been backed by Iran-based and Russia-supported Hezbollah, Shia Islamist militant groups, and also against each other. The civil war has further been a proxy war where many regional and global powers have been involved. The areas controlled by the combatting forces, the government, the YPG, and the IS, ${ }^{34}$ indicate the future division, at least the federative formation of Syria predominantly by the Alawites, Kurds, and the Sunni Arabs which has been on its way with the declaration of federation by the Kurds of Syria on March 17, 2016, largely rallied by the PYD.

Despite their dynamism in Syrian history, two margins of Syria's complicated politics, Sunni Arabs and Kurds, have become the centers of the Syrian conflict while attempting to define their own respective boundaries largely through the IS and the YPG in an era of upheaval. How Turkey and the United States have positioned themselves towards those opposition groups will

https://obamawhitehouse.archives.gov/the-press-office/2012/03/25/remarkspresident-obama-and-prime-minister-erdogan-turkey-after-bilatera March 25, 2012.

${ }^{34}$ Going beyond the current borders of Iraq and Syria, the geographic names used in the organization's title (IS), such as "Iraq/al-Iraq" and Syria/“al-Sham" or, alternately in Western usage, "the Levant" resonate the Arab nationalist aspirations of the nineteenth and early twentieth centuries for a "Greater Syria" encompassing the historical extension of the medieval Arab Muslim civilization in its golden age, to include the Levant countries, namely, Syria, Lebanon, Palestine, Israel, Jordan, Cyprus, and parts of Turkey and Egypt along with Iraq, which roughly overlaps with historic Mesopotamia sans current Syria and Kuwait. Çiçek (ed.), Syria in World War I: Politics, Economy, and Society. 


\section{Devrim ÜMITT}

determine not only the future of bilateral relations and the model partnership, but also that of Syria as the country's fragmentation has been prospective.

With the escalation of civil war and the brutality of the ISIS against their opponents including Kurds, Yezidis, Christians, and Shiites and its advance on Iraq and Syria while seizing predominantly the Kurdish villages near the Turkish border, the U.S. Central Intelligence Agency (CIA), in late 2013, under the discretion and direction of Obama, started a program of worth of one billion dollars to train and equip "moderate" Syrian rebels to fight the ISIS. Widely known as train-and-equip program (Eğit-donat in Turkish), aiming at the training and arming of 15, 000 rebels on a three-year timetable, was endorsed by Turkey along with Qatar, Bahrain, and Saudi Arabia. With the treaty of February 2014, where Turkey and the United States agreed "in principle," the program started in early May. Turkey pledged and managed to train 2, 000 rebels in Kırşehir, a midwestern Anatolia city, who were eventually sent into Syria to fight the Assad forces, ISIS, and other terror groups. ${ }^{35}$ Meanwhile, the Assad regime first time used chemical weapons in August 2013 and evoked the red-line of Obama who declared earlier that the deployment of chemical munitions would change the "calculus" of his administration for military intervention (The Washington Post, August 20, 2012). With the embarrassing failure of the U.S. to rescue the Western hostages, including two Americans, from ISIL and the beheading of them, Obama, in August 2014, launched the surveillance flights over Syria to detect the ISIS targets and requested the Congress to pass a budget of half-million-dollars to train and arm the selected "moderate" Syrian rebels to fight the ISIS and the Assad forces. ${ }^{36}$ The Congress swiftly endorsed the Presidential request and the US-led coalition airstrikes started in late September with the support of all Sunni Arab regimes against ISIL's strongholds mainly in northern Syria extending from Raqqa, the self-proclaimed capital of ISIL and, since June 2014, the self-declared seat of caliphate of the IS where the hostages were executed, to the eastern Iraqi border.

During the US-led airstrikes to which a wide range of Western countries participated, the U.S. turned to the YPG, especially following the failure of the train-and-equip-program, for its well-trained and well-equipped forces with wellenough-experience on the ground. The cooperation between the U.S. and the Kurdish militia opened a new chapter in Turkish-American relations which would

35 For various reasons, the United States ended the train-and-arm-program in early September 2015.

36 https://www.whitehouse.gov/the-press-office/2012/08/20/remarks-president-whitehouse-press-corps August 20, 2012. 
“Model Partnership" Between Turkey And The United States Revisited During The...

be the indicative of the imminent drifting apart of the parties and in the future of Kurds, Syria, Middle East, and the American policy in the region. The U.S. airstrikes of October 2014 over Kobanî, ${ }^{37}$ a predominantly Kurdish city by the Turkish border in northern Syria, had been under the severe siege of the ISIS since late 2014.

In the midst of these developments and shortly after the Presidential elections in Turkey in Summer 2014, Obama and Erdoğan, as the newly-elected President in his first gathering with the U.S. President, met on the margins of a NATO Leaders Summit in Wales in early September 2014. Given the ongoing conflict both in Syria and Iraq, Obama put more emphasis on Turkey as the "southern front of NATO" with a reference to its serving as a "bridge between Europe and the Middle East and the Muslim world" whereas Erdoğan once again took the occasion to make a unilateral reference to model partnership, two times, at the outset of his remarks, by underlying the cooperation in political, economic, cultural, and commercial terms. ${ }^{38}$ However, in the wake of Turkey's reluctant agreement with the opening of a life-corridor, strategic cooperation of the country became more vital to American national interests and security concerns.

Acknowledging the "robust economic partnership" between the parties, Vice President Biden in his gathering with Erdoğan on the sidelines of the Atlantic Council Energy and Economic Summit in Istanbul in late November 2014 put the record straight: "I would posit today that our partnership is as strong as it has ever been. Today, we are working closely together once again to meet the very pressing challenges of this moment, and to further the strategic partnership between Turkey and America." 39

Shortly after the early November 2015 elections from which AKP emerged triumphant, Turkey hosted the G-20 summit in Antalya, resort town only few hundred miles away from its Syrian border, in mid-November. Taking place in the wake of Paris terrorist attacks for which the French President could not attend, the attention of the summit shifted to counterterrorism, fight against the IS, and

${ }^{37}$ Kurdish city of Kobanî in northern Syria is known as such in Kurdish or as Ayn alArab in Arabic. https://obamawhitehouse.archives.gov/the-pressoffice/2014/10/19/readout-presidents-call-turkish-president-erdogan October 19, 2014. ${ }^{38}$ https://obamawhitehouse.archives.gov/the-press-office/2014/09/05/remarks-presidentobama-and-president-erdo-turkey-bilateral-meeting September 5, 2014.

39 https://obamawhitehouse.archives.gov/the-press-office/2014/11/22/statement-pressvice-president-joe-biden-and-turkish-president-recep-erd November 22, 2014 (Italics are mine). 


\section{Devrim ÜMITT}

the Syrian refugees, top ramifications of the Syrian conflict. Prior to the summit, Turkey detained many IS suspects in an effort to further legitimize its place in the fight against the IS (Euronews, November 6, 2015). Since it became more vulnerable to the IS terrorist attacks and had the highest Syrian refugees, Turkey was expected to share these concerns with the United States. However, given the deepening military cooperation between the U.S. and the YPG, Erdoğan was mainly occupied with a safe zone, free of the YPG, in northern Syria. His call for a no-fly and secure zone instigated no reverberations at the summit (The Atlantic, November 15, 2015). ${ }^{40}$ In the margins of the summit, Erdoğan and Obama had the chance for a bilateral meeting. As Turkey became much more involved in the U.S.-led coalition military operations both in Syria and Iraq, the strategic aspect of the relationship was further placed on the front. Still, Erdoğan took the opportunity to underline the position of Turkey, this time, with the phrase of "as model and strategic partner" in his closing remarks, whereas Obama continued to value his counterpart merely as a "NATO ally." 11

In the U.N. Climate Change Conference held in Paris in late 2015, Obama went a step further and evaluated the climate change "akın" to the threat of IS. On the margins of the Conference, coming after the contentious developments in Turkey, Erdoğan and Obama held a meeting following which Obama explained that the U.S. made clear to Turkey what they really wanted Erdoğan to do more "to seal its border with Syria, where ISIS fighters both join the fight in Syria and Iraq, and slip out for attacks in Europe." To "unseal" the area, which was actually Azaz-Jarabulus, the red-line of Turkey, Obama was ready to work with Turkey to combine the coalition airstrikes and the Turkish ground forces to be located on the Turkish side of Syria border (Roll Call, December 1, 2015; Hürriyet Daily News, December 2, 2015).

The U.N. Conference coincided with the immediate aftermath of Turkey's crisis with Russia. Recognizing Turkey as a NATO ally and its right to defend its territory and airspace, Obama worked for diplomatic solution as Russia was essential in the thick of a fight against IS, the "common enemy" (Reuters, December 1, 2015). While Moscow was behind Assad, Ankara and Washington wanted to see Assad go. Obama tried to convince Erdoğan to ease with Russia and seal its border with Syria. Turkey declined to deploy the Turkish ground

\footnotetext{
${ }^{40}$ https://obamawhitehouse.archives.gov/the-press-office/2015/11/16/fact-sheet-2015-g20-summit-antalya-turkey November 16, 2015.

${ }^{41} \mathrm{https}$ ://obamawhitehouse.archives.gov/the-press-office/2015/11/16/remarks-presidentobama-and-president-erdogan-turkey November 16, 2015.
} 
“Model Partnership" Between Turkey And The United States Revisited During The...

forces on the border to close the line since such deployment would require a number as high as 30,000 troops which was explained to be impractical and to trigger IS terrorist attacks and complicate the entrance of Syrian refugees into Turkey (Milliyet, December 3, 2015). During the Conference, Putin dismissed the Turkish calls for direct communication to resolve the crisis and accused Turkey of oil supply from IS. This was simply dismissed by Erdoğan as "slander" (Reuters, December 2, 2015). On the sidelines of the U.N. Conference, when Erdoğan and Obama gathered for a bilateral meeting, no party, including Erdoğan, pronounced the model partnership, which seemed to be an already unfashionable coinage for the American side. However, given the fact that the Conference took place in the wake of a Turkish-Russian crisis, Obama stressed the U.S. commitment to "Turkey's security and sovereignty," and its "right to defend itself and its airspace and its territory." 42

In an extensive interview of Jeff Goldberg, The Atlantic, with Obama in March 2016, shortly before the Nuclear Security Summit in Washington, D.C., Obama's statements about Erdoğan demonstrated the deepening mistrust between the parties (The Atlantic, April 2016; Gazeteport, March 11, 2016). Evaluating the Turkish-American relations back to his early days in office when Erdoğan was valued as a "moderate Islamist" who could "serve as a bridge between the United States and Muslims, Obama revealed his eventual "disappointment" about Erdoğan whom he defined as a "failure" for becoming an "autocratic" leader refraining from using his army to bring stability to Syria. Furthermore, on the eve of the summit, in a statement of the U.S. National Security Council released by the White House on a recent meeting between the American National Security Advisor and the Turkish Foreign Minister, the Turkish Government was "urged" to "uphold the universal democratic values enshrined in Turkey's constitution." 43

Therefore, Erdoğan received a cold reception at the D.C. airport ( $C N N$ Politics, March 29, 2016) on his arrival for the Nuclear Security Summit with no high rank American official to welcome him. During his brief visit, Erdoğan was also joined by his son-in-law, newly appointed minister following the November elections. Prior to the summit, the bilateral relations had further been

42 https://obamawhitehouse.archives.gov/the-press-office/2015/12/01/remarkspresident-obama-and-president-erdogan-republic-turkey-after December 1, 2015.

43 https://obamawhitehouse.archives.gov/the-press-office/2016/03/28/statementnational-security-council-spokesperson-ned-price-national March 28, 2016 (Italics are mine). See also, Acemoğlu, D. \& J. Robinson. Why Do Nations Fail: The Origins of Power, Prosperity and Poverty. London: Profile Books, 2012. 


\section{Devrim ÜMITT}

strained upon some undemocratic developments in Turkey which was criticized by Obama in reference to democracy and free speech. Hence, it was suggested that Obama not formally meet Erdoğan for his "fast path to autocracy" (New York Times, May 5-6, 2016). However, on the final day, the leaders gathered briefly in the White House without the cameras and not in the Oval Office. Afterwards, Obama admitted that he was "troubled" by Erdoğan over freedom of press and the Syrian civil war: "It is no secret that there are some trends within Turkey that I have been troubled with...I think the approach they have been taking toward the press is one that could lead Turkey down a path that would be very troubling" (Yahoo News, April 1, 2016). Erdoğan countered these concerns with “discontentment” (Hürriyet, April 3, 2016; Reuters, April 3, 2016).

Turkish President's visit to Washington was overall a disappointment and widened the gap between the countries. This was, apparently, ${ }^{44}$ in stark contrast to Erdoğan's visit of May 2013 when Obama praised then Premier Erdoğan for starting peace talks with the Kurdish insurgents and leading the country to economic prosperity. These were all before the suppression of the Gezi Park protests of June 2013 and the subsequent bribe and corruption allegations of December 2013 both which played their part in deterioration of the Turkish-

44 A massive leak, April 2016, from a Panama-centered law firm including parts on Turkey about various topics claims an otherwise atmosphere for the May 2013 meeting between Erdoğan, accompanied by the Head of National Intelligence Agency, and Obama, accompanied by the Secretary of State, where Obama warned that they were aware of what had been going on in the Turkish-Syrian border, thereby implicitly referring to the use of the border for foreign recruits and oil supply by the IS and as a staging area for its transborder terrorist attacks, http://www.cumhuriyet.com.tr/haber/dunya/509467/Panama_belgeleri..._iste_dunyanin

_kirli_camasirlari..._Turkiye_den_101_sirket.html April 4, 2016; https://panamapapers.icij.org/. In the light of the "Panama leaks," despite seemingly a most anticipated and fruitful gathering between Erdoğan and Obama in the Rose Garden of the White House in May 2013 even to the extent prior to which Obama penned a very ambitious op-ed with "East and West" oriented civilizational remarks (https://obamawhitehouse.archives.gov/the-press-office/2013/05/16/op-ed-presidentobama-partnership-delivers May 16, 2013), this time no party, including Erdoğan himself, mentioned the model partnership which might be the indicative of ongoing tension between the countries. In the meeting, while Obama maintained the similar lexicon for Turkey and the bilateral relationship, Erdoğan sufficed to define his counterpart as an "ally and friend" whilst bringing attention to the impressively increasing Turkish American trade in a ten-year period from $\$ 8$ billion to $\$ 20$ billion. https://obamawhitehouse.archives.gov/the-press-office/2013/05/16/joint-pressconference-president-obama-and-prime-minister-erdogan-turkey May 16, 2013. 
“Model Partnership” Between Turkey And The United States Revisited During The...

American relations. ${ }^{45}$ At a time when both leaders became more open about their own disappointment, Obama confessed in a June 2016 interview that even though he had hoped to build a "model partnership," between the U.S. and Turkey, "his expectations did not come true" (Politico, July 16, 2016). It was the first and only time that Obama, not even in an official setting, but was reported to have uttered the "model partnership," since the unplanned coinage of the notion in a joint press conference as abovementioned.

Hence, before the NATO summit in Warsaw in early July 2016, just one week before the coup attempt in Turkey, Erdoğan reiterated his position of linking the YPG to terrorism whereas the U.S. Department of State responded that their thoughts about the PYD and the YPG had not changed in that they had not been seeing the latter as a terrorist organization (Evrensel, July 8, 2016), thereby reaffirming their commitment to working with the YPG on the ground. Taking place following the terrorist attacks in Istanbul, Baghdad, and Medina, the summit focused on the fight against the IS and how NATO would confront the terrorist threats in Iraq, Syria, and North Africa. Since security and collection of intelligence were integral parts of counterterrorism, NATO and EU issued their first joint declaration on security cooperation with a pledge to collaborate on hybrid warfare and cyberwarfare. It was decided that AWACS surveillance jets of NATO would fly over Turkey to monitor Iraq and Syria from Turkey for the US-led coalition airstrikes. ${ }^{46}$ Making his last appearance as U.S. President at a NATO summit, Obama refused to hold a meeting with Erdoğan, and there held no bilateral meeting, but a stand-up-talk. With no tangible result, the talk borne only one of the last photos of the two leaders together as a souvenir. Even in his first bilateral meeting with Obama, on the margins of a G-20 summit in China in early September 2016, in the post-coup attempt period in Turkey, Erdoğan kept referring to "model partnership," while Obama, once again, sufficed to define Turkey as a "NATO ally" and a "critical member of the coalition against ISIL" with no reference at all to the concept. ${ }^{47}$

Despite the souring of the relations in the course of the Syrian conflict, Turkey maintained its position on the pronunciation of the "model partnership,"

http://ps-europe.org/reformulating-the-december-17-25-scandal/; https://obamawhitehouse.archives.gov/the-press-office/2013/06/04/remarks-vicepresident-american-turkish-council June 4, 2013.

46 North Atlantic Treaty Organization, Warsaw Summit Communiqué. http://www.nato.int/cps/en/natohq/official_texts_133169.htm.

${ }^{47}$ https://obamawhitehouse.archives.gov/the-press-office/2016/09/04/remarks-presidentobama-and-president-erdogan-turkey-after-bilateral, September 4, 2016. 
whereas the American emphasis on the "strategic" aspect of the partnership increased as the United States, never mentioning the concept at any official setting even for once, prioritized its fight against the IS and increasingly referred to universal democratic values. In fact, on the part of the United States, the ultimate re-definition of the bilateral relationship remained within the notion of "vital partnership."

In a globalized world, it would be impossible for Turkey to isolate itself and fight with each neighbor and partner. Surrounded by the increasing problems at home and abroad, Turkey, to tidy up the relations with Israel broken upon the Mavi Marmara incident of six years earlier and to melt the ices with Russia upon the downing of a Russian warplane by the Turkish jets of seven months earlier, labored well with the support of the United States, and the damaged relations with both countries were repaired. In June 2015, there reached an agreement, based on the mutual understanding of December 2015 (Reuters, December 17, 2015) between Turkey and Israel to reestablish the diplomatic relations at ambassadorial level while Israel pledged to aid the families of victims through a fund without formal compensation and to open one of its main cargo ports for humanitarian aid to Gaza Strip without releasing the blockade. Regarding Russia, on June 28, the very day of the Turkish-Israeli agreement, Turkey sent an apology letter to Russia where the former pledged to aid the pilot's family without the mention of compensation. Swiftly, Russia released the trade and tourism embargo. Furthermore, Turkey worked to improve its ties with Iran and reopen the channels of dialogue with Assad and President Abdel Fattah al-Sisi of Egypt (BBC News, July 13, 2016). Normalization of relations with Israel and Russia was a diplomatic victory for Erdoğan and for Obama mainly for mending the fences between Turkey and Israel as two weighty NATO allies in the Middle East and gaining Russia against the IS.

Diverging interests of Turkey and the United States during the Syrian conflict reflected on the peace initiatives as well. The long intentions to end the war borne successive, yet no successful results. Since stepping of Russia on the side of Assad changed the balance of power, Turkey and the United States concurred that Assad could play no role in a transitional period, but separated on who would represent the opposition in a transitional period. Given Turkey's opposition, the PYD participated to the peace talks initially under various Syrian

48 https://obamawhitehouse.archives.gov/the-press-office/2013/11/22/readout-vicepresident-biden-s-meeting-deputy-prime-minister-bulent-arin November 22, 2013. 
“Model Partnership" Between Turkey And The United States Revisited During The...

opposition groups. The International Syria Support Group (ISSG), which Turkey and the United States were also members of, started the Vienna talks ending with statements of commitment to the Geneva Communiqué of 2012, endorsed by a U.N. Resolution calling the convening of the Syrian government and opposition by January 2016, establishment of a credible government by July 2016 with a new constitution, and a fair election by July 2017.

\section{RESULT}

Largely drawing on the materials from the White House Archives, a wide array of Presidential collections, the present article demonstrates that "model partnership" was spontaneously constructed during a joint press conference of 2009 in Turkey between President Gül and President Obama and was officially referred by Turkey alone since then, thereby becoming the first study highlighting the origination stage of the concept which will lead to well-grounded analyses on Turkish-American relations based on the concept. The prospect for a bilateral relationship going beyond the traditional security concerns to establish a multilayered cooperation of mutually respected interests was promising for Turkey, particularly, and the United States. Similar policies pursued by both parties during the Arab uprisings in the MENA region demonstrated that a new mode of cooperation was achievable when the interests were common. However, the Syrian conflict, chiefly the civil war, manifests that the rapprochement might stumble down given the multilayered aspects of the civil war and how the parties addressed those aspects within their national interests and security concerns. The positions of Turkey and the United States towards the opposition groups became decisive in their fast drifting apart.

At the outset of the Syrian conflict, both Turkey and the United States sought ways to persuade President Assad for democratic reforms, but following the brutal suppression of the public demonstrations, they opted for his removal. Still, Obama's commitment to Assad's removal never reached the rhetoric of Erdoğan. Upon Russia's becoming a party to the Syrian civil war behind Assad, the United States weighed Russia for the fight against the IS, the uppermost American goal, whereas Turkey prioritized affiliating the YPG with terrorism, top Turkish security concern.

The United States recognized the outcome of the November snap elections in Turkey bearing the AKP as the ruling party. However, it was disturbed by Turkey for three main reasons. First, Obama frequently claimed the use of Azaz- 


\section{Devrim ÜMİT}

Jarabulus line for foreign recruits, oil supply and a way to slip out for the terrorist attacks of the IS. Second, he expected Turkey to put its boots on the ground on the Turkish-Syrian border to preempt these activities of the IS. Finally, Obama was further troubled by the allegedly fast rise of authoritarianism, impairing secularism, democracy, and human rights in Turkey.

Consequently, "model partnership," as much as an accidentally coined concept and a point of reference only by Turkey, lost its proper connotation in the turbulence of the Syrian conflict as Turkey and the United States increasingly took conflicting positions towards the opposition groups. The Syrian civil war at particular has become a manifestation to how both countries could grow apart when the interests are in conflict. The prospect for a challenge to the traditional pattern of bilateral relationship and the stability in the Middle East depend on the harmonization of the policies of Turkey and the United States in the region through a shared set of democratic values and principles.

\section{REFERENCES}

\section{Books}

Acemoğlu, D., \&, Robinson, J. (2012). Why Do Nations Fail: The Origins of Power, Prosperity and Poverty. Profile Books.

Çiçek, T. (2016). Syria in World War I: Politics, Economy, and Society. Routledge Press.

Davutoğlu, A. (2012). Stratejik Derinlik. Küre Yayınları.

MacLean, G. (2014). Abdullah Gül and the Making of New Turkey. Oneworld Publications.

\section{Book Chapter}

Ertem, H.S. ( 2011). Regionalism or Shift of Axis? Turkish-Syrian-Iranian Relations. Ö. Z. Oktav (Ed.), Turkey in the 21st Century: Quest for a New Foreign Policy. Ashgate Publishing.

\section{Article from e-journal}

Alirıza, B. (2009). President Obama's Trip to Turkey: Building a 'Model Partnership'. Turkey Project, April 2009, https://csis-websiteprod.s3.amazonaws.com/s3fs- 
"Model Partnership" Between Turkey And The United States Revisited During The...

public/legacy_files/files/media/csis/pubs/090408_turkey_update.pdf. Access date: 20.04.2021.

Çandar, C. (2009). Turkey's 'Soft Power' Strategy: A New Vision for a MultiPolar World. SETA Policy Brief, December, https://setadc.org/turkeyssoft-power-strategy-a-new-vision-for-a-multi-polar-world/. Access date: 20.04.2021.

Davutoğlu, A. (2012). Principles of Turkish Foreign Policy and Regional Political Structuring. TEPAV Turkey Policy Brief Series, 3, Turkey policy brief \#3, Davutoglu EN.indd (tepav.org.tr). Access date: 20.04.2021.

Üstün, K. (2012). US-TR Relations: Arab Spring and the Search for Model Partnership. SETA Perspective, May, US-Turkey Relations: Arab Spring And the Search for Model Partnership | | SETA (setav.org). Access date: 21.04.2021.

\section{Newspapers}

Crowley, M. (2016). Did Obama Get Erdogan Wrong? Politico, July 16, https://www.politico.com/story/2016/07/obama-turkey-225659. Access date: 22.04.2021.

Davutoğlu, A. (2004). Türkiye Merkez Ülke Olmalı. Radikal, February 26, http://www.radikal.com.tr/yorum/turkiye-merkez-ulke-olmali-702116/. Access date: 22.04.2021.

Goldberg, J. (2016). The Obama Doctrine: The U.S. President talks through his hardest decisions about America's role in the world. The Atlantic, April 4, http://www.theatlantic.com/magazine/archive/2016/04/the-obamadoctrine/471525/. Access date: 22.04.2021.

ABD: PYD ve YPG'ye olan bakışımız değişmedi. (2016). Evrensel, July 8, https://www.evrensel.net/haber/284568/abd-pyd-ve-ypgye-olan-

bakisimiz-degismedi. Access date: 23.04.2021.

Erdogan Obama meet in Canada discuss PKK, Israel, Iran. (2010). World Bulletin, June 27, http://www.worldbulletin.net/haber/60553/erdoganobama-meet-in-canada-discuss-pkk-israel-iran. Access date: 23.04.2021.

Erdoğan says no one can 'slander' Turkey over Islamic State oil claims. (2015). Reuters, December 2, http://www.reuters.com/article/us-mideast-crisisrussia-turkey-erdogan-idUSKBNOTL1ML20151202. Access date: 23.04.2021. 
Israel and Turkey reach preliminary deal to restore ties -Israeli official. (2015).

Reuters, December 17, http://uk.reuters.com/article/uk-israel-turkeyidUKKBN0U02N120151217. Access date: 23.04.2021.

Obama: Erdoğan bir fiyasko. (2016). Gazeteport, March 11, http://gazeteport.com/2016/obama-erdogan-bir-fiyasko-29535/. Access date: 25.04.2021.

Obama tells Erdoğan 'to close Syrian border.' (2015). Hürriyet Daily News, December 2, http://www.hurriyetdailynews.com/obama-tells-erdogan-toclose-syrian-border.aspx? pageID $=238 \& n I D=91986 \&$ NewsCatID $=352$. Access date: 25.04.2021.

Obama warns Erdogan's headed down troubling path. (2015). Yahoo News, April 2, https://www.yahoo.com/news/obama-warns-erdogans-turkeyheaded-down-troubling-path-225107873.html?ref=gs. Access date: 25.04.2021.

Panama Belgeleri. (2016). Cumhuriyet, April 4, http://www.cumhuriyet.com.tr/haber/dunya/509467/Panama_belgeleri..._ iste_dunyanin_kirli_camasirlari..._Turkiye_den_101_sirket.html Access date: 25.04.2021.

Turkey detains 20 ISIL suspects in Antalya ahead of G20 summit. (2015). Euronews, November 6 (Last updated), http://www.euronews.com/2015/11/06/turkey-detains-20-isil-suspects-inantalya-ahead-of-g20-summit/. Access date: 25.04.2021.

Turkey gives the cold shoulder to US proposal. (2015). Milliyet, December 3, http://www.milliyet.com.tr/turkey-gives-the-cold-shoulder-to-usproposal-to-en-2157790/en.html. Access date: 26.04.2021.

\section{Official documents, \&, Archives}

IMF. Report for Selected Countries and Subjects. IMF World Economic Outlook Database, April 2015.

North Atlantic Treaty Organization. Warsaw Summit Communiqué. http://www.nato.int/cps/en/natohq/official_texts_133169.htm. Access date: 13.04.2021.

The American Presidency Project. The President's News Conference With President Abdullah Gul of Turkey in Ankara, Turkey. http://www.presidency.ucsb.edu. Access date: 24.03.2021. 
"Model Partnership" Between Turkey And The United States Revisited During The...

The International Consortium of Investigative Journalists. The Panama Papers. https://panamapapers.icij.org/. Access date: 26.04.2021.

UNHCR. https://data.unhcr.org/syrianrefugees/country.php?id=224 Access date: 16.07.2016.

White House. Obama White House Archives. https://obamawhitehouse.archives.gov/briefing-room/speeches-andremarks. Access date: 13.04.2021.

White House. https://obamawhitehouse.archives.gov/issues/foreignpolicy/presidents-speech-cairo-a-new-beginning. Access date: 13.04.2021.

White House. https://obamawhitehouse.archives.gov/the-press-office/readoutpresidents-call-with-turkish-president-gul. Access date: 13.04.2021.

White House. https://obamawhitehouse.archives.gov/the-pressoffice/2011/09/20/remarks-president-obama-and-prime-minister-erdoganturkey-bilateral-meet .Access date: 13.04.2021.

White House. https://obamawhitehouse.archives.gov/the-pressoffice/2012/03/25/remarks-president-obama-and-prime-ministererdogan-turkey-after-bilatera .Access date: 26.04.2021.

White House. https://www.whitehouse.gov/the-pressoffice/2012/08/20/remarks-president-white-house-press-corps. Access date: 30.04 .2021 .

White House. https://obamawhitehouse.archives.gov/the-pressoffice/2013/05/16/op-ed-president-obama-partnership-delivers. Access date: 30.04 .2021 .

White House. https://obamawhitehouse.archives.gov/the-pressoffice/2013/05/16/joint-press-conference-president-obama-and-primeminister-erdogan-turkey. Access date: 30.04.2021.

White House. https://obamawhitehouse.archives.gov/the-pressoffice/2013/06/04/remarks-vice-president-american-turkishcouncil.Access date: 03.05.2021.

White House. https://obamawhitehouse.archives.gov/the-pressoffice/2013/11/22/readout-vice-president-biden-s-meeting-deputy-primeminister-bulent-arin. Access date: 03.05.2021. 


\section{Devrim ÜMİT}

White House. https://obamawhitehouse.archives.gov/the-pressoffice/2014/09/05/remarks-president-obama-and-president-erdo-turkeybilateral-meeting. Access date: 03.05.2021.

White House. https://obamawhitehouse.archives.gov/the-pressoffice/2014/10/19/readout-presidents-call-turkish-president-erdogan.

Access date: 05.05.2021.

White House. https://obamawhitehouse.archives.gov/the-pressoffice/2014/11/22/statement-press-vice-president-joe-biden-and-turkishpresident-recep-erd.Access date: 05.05.2021.

White House. https://obamawhitehouse.archives.gov/the-pressoffice/2015/03/26/readout-president-s-call-president-recep-tayyiperdogan-turkey. Access date: 12.05.2021.

White House. https://obamawhitehouse.archives.gov/the-pressoffice/2015/04/21/statement-nsc-spokesperson-bernadette-meehannational-security-advisor-.Access date: 13.05.2021.

White House. https://obamawhitehouse.archives.gov/the-pressoffice/2015/11/16/fact-sheet-2015-g-20-summit-antalya-turkey.Access date: 17.05.2021.

White House. https://obamawhitehouse.archives.gov/the-pressoffice/2015/11/16/remarks-president-obama-and-president-erdoganturkey. Access date: 18.05.2021.

White House. https://obamawhitehouse.archives.gov/the-pressoffice/2015/12/01/remarks-president-obama-and-president-erdoganrepublic-turkey-after. Access date: 19.05.2021.

White House. https://obamawhitehouse.archives.gov/the-pressoffice/2015/12/09/remarks-president-obama-and-president-rivlin-israelbilateral-meeting.Access date: 19.05.2021.

White House. https://obamawhitehouse.archives.gov/the-press-office/remarkspresident-and-pm-turkey-after-meeting. Access date: 21.05.2021.

White House. https://obamawhitehouse.archives.gov/the-pressoffice/2016/03/28/statement-national-security-council-spokespersonned-price-national.Access date: 23.05.2021.

White House. https://obamawhitehouse.archives.gov/the-pressoffice/2016/09/04/remarks-president-obama-and-president-erdoganturkey-after-bilateral.Access date: 23.05.2021. 
"Model Partnership" Between Turkey And The United States Revisited During The...

White House. https://obamawhitehouse.archives.gov/the-pressoffice/2016/11/16/remarks-president-obama-stavros-niarchos-foundationcultural-center. Access date: 24.05.2021.

White House. https://obamawhitehouse.archives.gov/the-press-office/remarkspresident-barack-obama-student-roundtable-istanbul. Access date: 25.05.2021.

White House. https://obamawhitehouse.archives.gov/the-press-office/remarkspresident-obama-and-prime-minister-erdogan-turkey-after-meeting.

Access date: 25.05.2021.

White House. https://obamawhitehouse.archives.gov/video/Addressing-theTurkish-Parliament. Access date: 25.05.2021.

White House. https://www.whitehouse.gov/the-press-office/joint-pressavailability-with-president-obama-and-president-gul-turkey. Access date: 25.05.2021.

White House. https://www.whitehouse.gov/the-press-office/remarks-presidentand-pm-turkey-after-meeting. Access date: 25.05.2021.

White House. https://www.whitehouse.gov/the-pressoffice/2012/08/20/remarks-president-white-house-press-corps. Access date: 26.05.2021.

\section{Research Articles}

Başer, E. (2015). Shift of Axis in Turkish Foreign Policy: Turkish national role conceptions before and during AKP rule. Turkish Studies, 16, 291-309.

Han, A. K. (2010). From "Strategic Partnership" to "Model Partnership": AKP, Turkish-US Relations and the Prospects under Obama. UNISCI Discussion Papers, May, https://www.redalyc.org/pdf/767/76715004006.pdf. Access date: 11.04.2021.

Kardaş, Ş. (2011). Turkish-American Relations in the 2000s: Revisiting the Basic Parameters of Partnership? Perceptions, 16, 816443 (dergipark.org.tr). Access date: 16.04.2021.

Oğuzlu, T. (2008). Middle Easternization of Turkish Foreign Policy: Does Turkey Disassociate from the West. Turkish Studies, 9, 3-20.

Öniş, Z. (2011). Multiple Faces of the New Turkish Foreign Policy: Underlying Dynamics and Critique. Insight Turkey, 13, (PDF) Multiple faces of the 


\section{Devrim ÜMITT}

"new" Turkish foreign policy: Underlying dynamics and a critique (researchgate.net). Access date: 07.05.2021.

Özhan, T. (2010). Turkey, Israel, and the US in the Wake of the Gaza Flotilla Crisis. Insight Turkey, 12/3, Turkey, Israel and the US in the Wake of the Gaza Flotilla Crisis, Commentaries Taha Özhan | Insight Turkey. Access date: 16.05.2021.

Şahin, M. (2011). Islam, Ottoman Legacy, and Politics in Turkey: An Axis of Shift. The Washington Review of Turkish and Euroasian Affairs, January, http://www.thewashingtonreview.org/articles/islam-ottoman-legacy-andpolitics-in-turkey-an-axis-shift.html. Access date: 17.05.2021.

Y1lmaz, N. (2011). US-Turkey Relations: Model Partnership as an 'Empty Signifier.' Insight Turkey, 13/1 U.S.-Turkey Relations: Model Partnership as an 'Empty Signifier', Commentaries Nuh Yilmaz | Insight Turkey. Access date: 18.05.2021.

\section{EXTENDED ABSTRACT}

Turkey and the United States enjoyed a security-centered relationship upon the former's becoming a member of the North Atlantic Treaty Organization (NATO) in 1952. This was challenged with an envision of model partnership in 2009 to transform the relationship into a multidimensional cooperation with the mutual interests respected. This article aims at the careful re-reading of the construction stage of "model partnership" to demonstrate how the concept was spontaneously spelled out and the examination of the Turkish-American relations based on the concept during the Syrian conflict up until the coup attempt of July 15, 2016 in Turkey. Therefore, the present study largely draws on the materials from the White House Archives, a wide array of Presidential collections, including speeches and remarks, press briefings, and statements and releases. As the article also argues of a model shift taking place from Cold War bilateralism to regional balancing during the Syrian conflict, it has a legitimate emhphasis on newspaper accounts as well since they played such a significant role in the shaping of local

public opinion. The article does not restrict itself to a debate of theoretical analyses or targeting at quantative approach. The present study, being the first study to highlight how the concept first aired by chiefly drawing on the archival materials, demonstrates that the "model partnership" was spontaneously uttered 
“Model Partnership” Between Turkey And The United States Revisited During The...

by the U.S. President Barack Obama in the question and answer session of a joint press conference held between himself and Turkish President Abdullah Gül during the former's first official visit to Turkey in 2009. The notion was neither a U.S. or a Turkish pre-formulated nor a mutually endorsed policy concept, but was pronounced naturally by the U.S. President within a civilizational connotation and remained as a unilaterally referred policy item by Turkey. The article further indicates that the prospect for a bilateral relationship going beyond the traditional security concerns to establish a multilayered cooperation of mutually respected interests was promising for Turkey, particularly, and the United States. Similar policies pursued by both parties during the Arab uprisings in the Middle East and North Africa region demonstrated that a new mode of cooperation was achievable when the interests were common. However, the Syrian conflict, primarily the civil war, manifests that the rapprochement might stumble down given the multilayered façades of the civil war and how the parties addressed those façades within their national interests and security concerns. The positions of Turkey and the United States towards the opposition groups in the Syrian civil war became decisive in their fast drifting apart. At the outset of the Syrian conflict, both Turkey and the United States sought ways to persuade President Basher Hafez al-Assad for democratic reforms, but following the brutal suppression of the public demonstrations, they opted for his removal. Still, Obama's commitment to Assad's removal never reached the rhetoric of Turkish Premier, later on, Turkish President Recep Tayyip Erdoğan. Upon Russia's becoming a party to the Syrian civil war behind Assad, the United States weighed Russia for the thick fight against the IS, which was the uppermost American goal, whereas Turkey prioritized affiliating the YPG with terrorism, which was the top Turkish security concern. The present study concludes that looking into the construction stage of the notion, principally within the U.S. Presidential archival materails, will bear well-grounded analyses on Turkish-American relations based on the concept and that the complexity of the Syrian conflict, particularly the divergent positions of the parties towards the opposition groups in the Syrian civil war, called this process into question as both Turkey and the United States did not find easy agreement on aspects of their national interests and security concerns and fast moved away from the "model partnership," a vague redefinition of bilateral relations and a concept officially referred by Turkey alone. As a result, "model partnership," as much as an accidentally coined concept and a point of reference only by Turkey, lost its proper connotation in the turbulence of the Syrian conflict as Turkey and the United States increasingly took conflicting positions towards the opposition groups. The Syrian civil war at particular has become a manifestation to how both countries could grow apart when the interests are in conflict. The prospect for a challenge to the traditional pattern of bilateral 


\section{Devrim ÜMİT}

relationship and the stability in the Middle East depend on the harmonization of the policies of Turkey and the United States in the region through a shared set of democratic values and principles. 